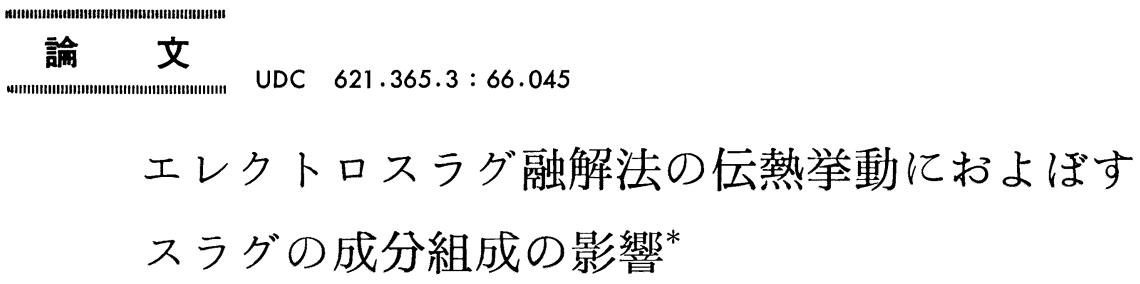

草道龍彦** . 石井照朗 ${ }^{* *}$. 尾上俊雄 $* *$. 成田貴一***

\title{
Effect of Composition of Slag on Heat Transfer Characteristics in Electroslag Remelting Process
}

\author{
Tatsuhiko Kusamichi, Teruo Ishir, Toshio Onoye, and Kiichi Narita
}

\section{Synopsis:}

Temperature distribution in slag bath and heat transfer rate to cooling water at various interfaces were investigated on $80 \mathrm{~mm} \phi$ ESR furnace. Effective thermal conductivity of slag crust was also measured. $\mathrm{CaO}-\mathrm{Al}_{2} \mathrm{O}_{3}-\mathrm{CaF}_{2}$ slags were used in these experiments. Effects of heat transfer characteristics on melting rate and the shape of metal bath are discussed.

The results obtained are as follows:

(1) Overall heat transfer coefficient of the interface region between slag bath and cooling water in ESR and effective thermal conductivity of $\mathrm{CaO}-\mathrm{Al}_{2} \mathrm{O}_{3}$ are $0.014 \mathrm{cal} / \mathrm{cm}^{2} \cdot \mathrm{s} \cdot \mathrm{deg}$ and $2.2 \times 10^{-3} \mathrm{cal} / \mathrm{cm} \cdot \mathrm{s} \cdot \mathrm{deg}$, respectively, and they both increase with the increase in $\mathrm{CaF}_{2}$ content.

(2) In case of oxide-base slag, temperature in slag bath gradually decreases in radical directions, but in fluoride-base one, it doesn't change so much to the vicinity of slag crust.

(3) The temperature gradient in slag crust of $\mathrm{CaO}-\mathrm{Al}_{2} \mathrm{O}_{3}$ slag is very steep. However, it becomes gentle and the temperature gap at the slag crust-mold wall interface increases with the increase in $\mathrm{CaF}_{2}$ content.

(4) The shape of metal bath differs according to slag composition. Its depth depends on the temperature of slag bath. On the other hand, the height of the cylindrical part of metal bath is related to the heat transfer rate across the slag bath-metal bath interface.

\section{1. 緒言}

エレクトロスラグ融解 $(\mathrm{ESR})$ 法においては，金属電 極をスラグ浴の電気的抵抗熱によつて融解し, 溶融メタ ル滴としてスラグ浴中を落下させメタル浴をつくるとと もに, いつぽうでは, 水冷鋳型によつて連続的に冷却し て逐次凝固させる。したがつて適正な融解を行い，健全 な凝固組織を有する鋳塊をつくるためには，スラグ浴に お汀る発熱拉よび伝熱挙動を知ることがきわめて重要で ある。

スラグ浴における発熱現象を知る一つの手段としてス ラグ浴の温度分布1) 3) や電位分布1)2 が測定されて括り， またスラグの流動現象については電磁気力に基づく解 析) -6)が行われて扮り，スラグ浴の動きはかなり激し
く，その温度は此較的均一で㘯るといわれている。スラ グ浴の電気的抵抗熱の一部は電極の融解に消費され, 一 部はスラグ浴表面からの伝熱および鋳塊や鋳型を通して の伝熱によつて失われる. MITGHELL ら ${ }^{1)}$ は鋳型壁の温 度分布の測定をもとにスラグ浴からの伝熱量を求め，ま たPATON ら7) は種々の鋳型拈よび融解方式についての 熱収支を示している。これらによると，スラグ浴で発生 した熱のらち電極の融解に用いられる熱を含めて 30〜 $40 \%$ がメタル浴に，末た 40〜60\% が直接鋳型に伝熱さ れる. MitchelL ら ${ }^{8)}$ はさらにスラグ浴-冷却水間の総括 伝熱係数および文献から見積もつたスラグ殼の熱伝導率 を用いてスラグ浴一冷却水間の温度勾配を求め，スラグ 殸一鋳型間に温度差が存在することを示している。また， 飯島ら9) は種々のフッ化物系スラグについて，水冷銅管

* 昭和 54 年 4 月本会講演大会にて発表 昭和 54 年 11 月 29 日受付 (Received Nov. 29, 1979)

** (株) 神戸製鋼所中央研究所 (Central Research Laboratory, Kobe Steel, Ltd., 1-3-18 Wakinohama-cho Fukiai-ku Kobe 651)

*** (株)神戸製鋼所中央研究所 工博 (Central Research Laboratory, Kobe Steel, Ltd.) 
をスラグ浴に浸漬し,スラグ浴-冷却水間の総括伝熱係数 およびスラグ殸厚さとスラグ浴温度の関係を求めてい る.しかしながら，これら伝熱挙動はいずれもフッ化物 系スラグについての結果であり，スラグの成分組成の影 響や酸化物系スラグについては明らかではない。またス ラグ款の熱伝導率は， $\mathrm{CaF}_{2}$ や $\mathrm{Al}_{2} \mathrm{O}_{3}$ などの単一物質に ついての值は知られているが，ESR 用スラグについて の寒測健はほとんぞ報告されていない。

いつ添う，著者ら ${ }^{10)}$ は投入電力之融解速度の関係がス ラグの成分組成によつて大きく異なることを明らかにし た。すなわち， $\mathrm{CaO}-\mathrm{Al}_{2} \mathrm{O}_{3}$ を主成分とする酸化物系下 ラグを適用した湯合，従来のフッ化物系スラグと比べて 同一投入電力に対し融解速度は 20 40\% 增加し，電力 原単位が低減するが，これは酸化物系スラグではスラグ 浴から鋳型への熱損失が少ないためであると推定した。 また，鈴木ら ${ }^{11}$ は酸化物系スラグを使用した場合，同一 融解速度に対しメタル浴中央部の深さは従来のフッ化物 系スラグと変わらないが，×タル浴円柱部*の高さが小 さくなり，デンドライトの成長方向を示す水平面に対す る傾きが小さくなると述べている。これらの結果はいず 机もスラグ浴-鋳型間に生成するスラグ殸を通しての伝 熱挙動の違いによるところが大きいと考えられる.

そこで本研究においては，伝熱挙動におよぼすスラグ の成分組成の影響を明らかにすることを目的とし，種々 のスラグを用いて融解を行い，鋳型の温度分布および冷 却水一の伝熱速度を測定し,スラグ浴-鋳型内冷却水間, メタル浴一泠却水間の各界面を通しての総括伝熱係数を 求めた。またスラグ殸の熱伝導率は，水冷銅管をスラグ 浴に浸漬し12)，スラグ殸内の温度を直接測定する方法に より求めた．これらの結果に基づいて融解速度や鋳塊品 質と伝熱挙動との関係について考察を行つた。

\section{2. 実験装置および方法}

\section{$2 \cdot 1$ ESR における层熱挙動}

融解用電源は容量 $100 \mathrm{kVA}$, 最大 2 次電流 $1800 \mathrm{~A}$ の 交流アーク溶接用トランスであり, 鋳型は水冷伝熱面が 直接観察できるように透明アクリ儿樹脂を用いて外筒部

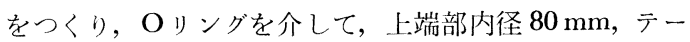
： $1 / 58$ の銅製内筒と接合した．鋳型には温度分布測定 のために内筒の Fig. 1 の知印の位置に, シース型クロ ィルーアルメル $(\mathrm{CA})$ 熱電対を埋めこみ (深さ $3 \mathrm{~mm})$, また冷却水温度の測定用にシース型 $\mathrm{CA}$ 熱電対を鋳型 壁から十分離れた位置に設置した。なお，炉底冷却水温 度はその入口および出口で測定した。

*×タル浴において鋳型壁まで涳融状態にある円柱状の領域をいう.
電極材は $45 \mathrm{~mm} \phi$ の炭素鋼（S48C）であり，スラグ は試薬を所定の成分組成に混合し，あらかじめタンマン 㭁で溶製した $\mathrm{CaO}-\mathrm{Al}_{2} \mathrm{O}_{3}$ 抒よび $\mathrm{CaO}-\mathrm{Al}_{2} \mathrm{O}_{3}-\mathrm{CaF}_{2}$ 系 スラグを用いた。

融解は大気雾用気下でュールド・スタート法により行 つた．融解中の電流および電極一炉底艋間電圧は連続的 に記録し，鋳型壁㧍よび冷却水の温度は多点式ディジタ ル記録計を用いて $30 \mathrm{~s}$ ごとに記録した。

融解終了時には $\mathrm{Fe}-\mathrm{S}$ 合金をメタル浴およびスラグ浴 に同時に添加し，サルファ・プリントにより，メタル浴 の大きさおよびスラグ浴での凝固スラグ殸厚さを測定し た.

スラグの成分組成の影響に関する垁験は，ほぼ一定の 融解速度で行い，融解速度の影響は， $\mathrm{CaO}-\mathrm{Al}_{2} \mathrm{O}_{3}-\mathrm{CaF}_{2}$ (37.5/37.5/25) スラグについて行つた. 使用したスラグ 量はいずれの場合も500 gであり，電流は800〜1500A， 電圧は $20 \sim 30 \mathrm{~V}$ である.な掞冷却水流量は，鋳型およ び炉底とも $11 \mathrm{l} / \mathrm{min}$ となるように調節した。

\section{$2 \cdot 2$ スラグ殼の有効熱伝導率}

装置の概略を示すと Fig. 2 のとおりであり，黒鉛る つぼ（内径 $38 \mathrm{~mm}$ ) 内でスラグ $120 \mathrm{~g}$ を融解し, 溶融ス ラグ中に水冷銅管を浸漬して，冷却水の温度上昇および スラグ殸内の温度を測定した．加熱はアルゴン雾囲気下 でタンマン炉を用いて行い，炉の温度はるつぼ底部に設 置した熱電対により制御した。水冷銅管は外径 $10 \mathrm{~mm}$ または $12 \mathrm{~mm}$ ，内径 $8 \mathrm{~mm}$ の純銅製であり，その内部 に外径 $6 \mathrm{~mm}$ ，内径 $4 \mathrm{~mm}$ のアルミナ管を插入した 2 重 管構造である. 冷却水流量は水位を一定にした水槽を用

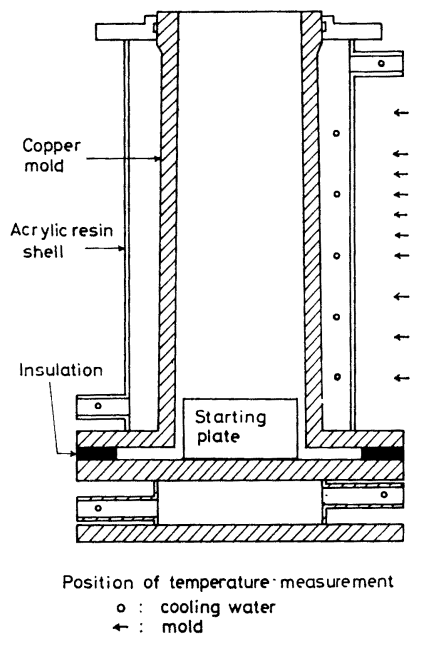

Fig. 1. Mold and arrangement of thermocouples for measuring heat flow in ESR. 


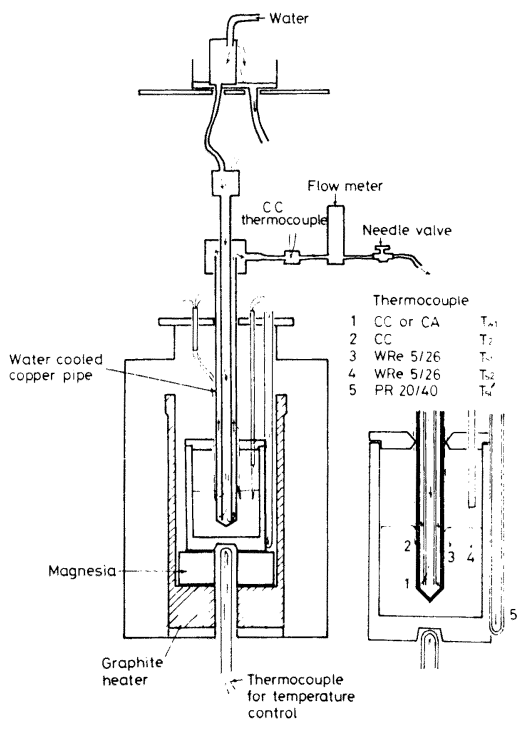

Fig. 2. Experimental apparatus for measuring effective thermal conductivity of slag crust.

いて最大流量および生力変動を制御し，ニードル・バル ブにより微調節した．水温は銅管内のスラグ浴に相当す る位置および銅管出口でクロメルーアルメルまたは銅ーュ ンスタンタン熱電対により，また，銅管外壁の温度は銅 管自体を@極として,銅-コンスタンタン熱電対を形成し て測定し，スラグ款の温度は銅管壁より 2 および $10 \mathrm{~mm}$ の位置でタングステンーレニウム $(\mathrm{W} 5 \% \mathrm{Re} / \mathrm{W} 26 \% \mathrm{Re})$ 熱電対により測定した.

実験はまずスラグを溶かし，スラグ浴が所定の温度に 達したとき，銅管をその先端がわずかにスラグ浴に浸漬 する状態に插入して, 冷却水出口温度を測定し，これを 空測定值とする. 次に銅管をスラグ浴中に約 $30 \mathrm{~mm}$ 挿 入する.この場合, 液面の上昇があるので, これを補正 して浸漬深さを正確に $30 \mathrm{~mm}$ に保持し, 銅管出口の水 温が一定となつたのち, 水温および銅管ースラグ浴間のス ラグ殼の温度および銅管外壁の温度を測定した..なお， 銅管浸漬状態に打沙るスラグ浴の垂直方向の温度勾配は 土5C 以下となるようにるつぼを設置した。

銅管をスラグ浴に浸漬した直後，水温は急激に上昇す るが，徐々に水温は低下し，約 $50 \mathrm{~s}$ で一定の温度とな り, 定常状態に達する. これは浸漬後, 凝固スラグ殸が 銅管周囲に形成されるとともに流入熱量が減少し, やが て冷却水の冷却能力と炉からの供給熱量が均衡し, 一定 のスラグ殼厚さになり，熱的定常状態に達するためであ ると考えられる.

定常状態において, スラグ浴一銅管内冷却水間の伝熱速

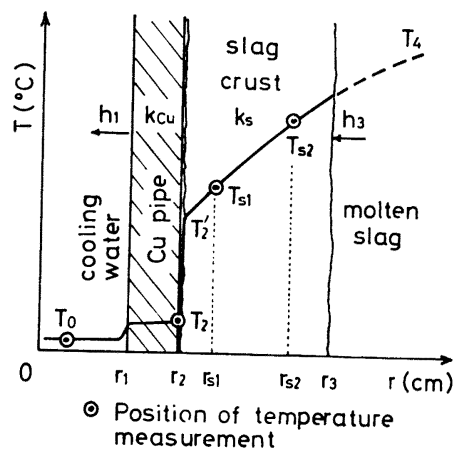

Fig. 3. Schematic diagram of a temperature gradient between slag bath and cooling water.

度 $q(\mathrm{cal} / \mathrm{s})$ は浸漬後の出口水温と空測定值との差 $\Delta T$ $\left({ }^{\circ} \mathrm{C}\right)$ 打よび冷却水流量 $L\left(\mathrm{~cm}^{3} / \mathrm{s}\right)$ から (1) 式で求めら れる.

$$
q=\rho C L \Delta T
$$

ここで， $\rho, C$ はそれぞれ水の密度 $\left(\mathrm{g} / \mathrm{cm}^{3}\right)$ および比熱 (cal/g·deg) である.いつぽう，スラグ浴-スラグ殸-銅 管一冷却水間の伝熱状況を模式的に示すと Fig. 3 のとお りであり，スラグ殼の 有効熱伝導率 $k_{\mathrm{s}}(\mathrm{cal} / \mathrm{cm} \cdot \mathrm{s} \cdot \mathrm{deg})$ は (1) 式と (2) 式により求められる.

$$
q=2 \pi l k_{\mathrm{s}}\left(T_{\mathrm{s} 2}-T_{\mathrm{s} 1}\right) / \ln \left(r_{\mathrm{s} 2} / r_{\mathrm{s} 1}\right)
$$

ここで, $l$ はスラグ浴への銅管浸漬深さ $(\mathrm{cm}), T_{\mathrm{s} 1}, T_{\mathrm{s} 2}$ はスラグ殸内の温度 $\left({ }^{\circ} \mathrm{C}\right), r_{\mathrm{s} 1}, r_{\mathrm{s} 2}$ は温度測定位置 $(\mathrm{cm})$ である.またスラグ浴-銅管内冷却水間の総括伝熱係数 $U_{\mathrm{r}_{2}}\left(\mathrm{cal} / \mathrm{cm}^{2} \cdot \mathrm{s} \cdot \mathrm{deg}\right)$ \& (1) 式と (3) 式により求められ る.

$$
q=2 \pi r_{2} l U_{\mathrm{r} 2}\left(T_{4}-T_{0}\right)
$$

ここで， $r_{2}$ は銅管外径 $(\mathrm{cm}), T_{4}, T_{0}$ はそれぞれスラグ 浴温度およびスラグ浴相当領域の銅管内冷却水温度 $\left({ }^{\circ} \mathrm{C}\right)$ である・

な拉，冷却水流量は伝熱速度 $q$ に影響を与えるが，予 備実験の結果によれば, 銅管壁-冷却水間の伝熱抵抗はス ラグ浴-冷却水間の全伝熱抵抗に比べて $6 \%$ 程度であり, かなり小さいことから本実験では流量の影響は検討せ ず，10〜12 mm のスラグ殸が生成するような冷却水流量

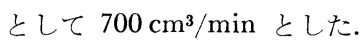

実験に供したスラグは $\mathrm{CaO}-\mathrm{Al}_{2} \mathrm{O}_{3}-\mathrm{CaF}_{2}$ 系スラグで あり，その成分組成を示すと Table 1 のと抢りである。 スラグはいずれも試薬を所定の組成に混合し，タンマン 炬で融解したのち，鉄板上に流出させて急冷したもので ある。な拈，Table 1 には参考までに状態図 ${ }^{13)}$ から推定 される融点および示差熱分析によつて測定した融点を併 記した。 
Table 1. Chemical composition of the slag used.

\begin{tabular}{c|c|c|c|c|c}
\hline \multirow{2}{*}{ Slag } & \multicolumn{2}{|c|}{ Chemical composition $(\mathrm{wt} \%)$} & \multicolumn{2}{c}{ Liquidus temp. ( $\left.{ }^{\circ} \mathrm{G}\right)$} \\
\cline { 2 - 6 } & $\mathrm{CaO}$ & $\mathrm{Al}_{2} \mathrm{O}_{3}$ & $\mathrm{CaF}_{2}$ & $*$ & $*$ \\
\hline $\mathrm{CaO}-\mathrm{Al}_{2} \mathrm{O}_{3}$ & 50 & 50 & - & 1360 & 1400 \\
$\mathrm{CaO}-\mathrm{Al}_{2} \mathrm{O}_{3}-\mathrm{CaF}_{2}$ & 40 & 17 & 43 & 1193 & 1220 \\
$\left(\mathrm{CaO}-\mathrm{Al}_{2} \mathrm{O}_{3}\right)-25 \mathrm{CaF}_{2}$ & 37.5 & 37.5 & 25 & 1460 & 1470 \\
$\left(\mathrm{CaO}-\mathrm{Al}_{2} \mathrm{O}_{3}\right)-50 \mathrm{CaF}_{2}$ & 25 & 25 & 50 & 1405 & 1410 \\
$\left(\mathrm{CaO}-\mathrm{Al}_{2} \mathrm{O}_{3}\right)-75 \mathrm{CaF}_{2}$ & 12.5 & 12.5 & 75 & 1390 & 1405 \\
$\left(\mathrm{CaO}-\mathrm{Al}_{2} \mathrm{O}_{3}\right)-90 \mathrm{CaF}_{2}$ & 5 & 5 & 90 & 1380 & 1340 \\
$\mathrm{CaF}_{2}$ & - & - & 100 & 1423 & 1380 \\
\hline
\end{tabular}

* From phase diagram ${ }^{13}$ ) ** Measured by DTA

\section{3. 結果および考察}

\section{3 -1 ESR における伝熱挙動}

ESR 法の全融解過程における，鋳型および炉底盤出 口の冷却水温度 $T_{\text {mold }}, T_{\text {bottom }}\left({ }^{\circ} \mathrm{C}\right)$, スラグ浴に拈け る発熱速度 $q_{\mathrm{ex}}(\mathrm{cal} / \mathrm{s})$ および冷却水への伝熱速度 $q_{\mathrm{w}}$ $(\mathrm{cal} / \mathrm{s})$ の時間変化の一例を示すと Fig. 4 のと物りで ある. $q_{\mathrm{ex}}$ および $q_{\mathrm{w}}$ はそれぞれ (4) 式および (5) 式で 表すことができる.

$$
\begin{aligned}
q_{\mathrm{ex}}= & J I E \\
q_{\mathrm{w}}= & q_{\mathrm{mold}}+q_{\text {bottom }} \cdots \ldots \ldots \ldots \ldots \ldots \ldots \ldots \ldots(5) \\
& q_{\mathrm{mold}}=\rho C L_{\mathrm{mold}}\left(T_{\mathrm{mold}}-T_{\mathrm{in}}\right) \cdots \cdots \cdots(5)^{\prime} \\
& q_{\text {bottom }}=\rho C L_{\text {bottom }}\left(T_{\text {bottom }}-T_{\text {in }}\right) \cdots(5)^{\prime \prime}
\end{aligned}
$$

ここで， $J=0.239 \mathrm{cal} / \mathrm{W} \cdot \mathrm{s} ， I ， E$ はそれぞれスラグ浴 への投入電流 $(\mathrm{A})$ およびスラグ浴電压 $(\mathrm{V}), q_{\mathrm{mold}}$, $q_{\text {bottom }}$ はそれぞれ鋳型および炉底盤冷却水への伝熱速 度 $(\mathrm{cal} / \mathrm{s}) ， T_{\mathrm{in}}$ は鋳型拈よび炉底盤入口の冷却水温度 $\left({ }^{\circ} \mathrm{C}\right)$ である.なお，ESR では電極先端にお汁る融滴の 生成・離脱による電極一メタル浴間距離の変化に応じて, 電流および電圧が変動するために，I 㧊よび $E$ の值と して，石井ら ${ }^{14)}$ と同様の才法により求めた平均值を用い た。

融解初期はスラグの融解や鋳型・電極などへの伝熱 · 昇温に多量の熱量を要するため, $q_{\mathrm{ex}}$ と $q_{\mathrm{w}}$ の差は大き い. スラグが完全に溶け，電極の融解速度がほぼ一定と なる定常融解期は， $q_{\mathrm{ex}}$ と $q_{\mathrm{w}}$ がほぼ均衡し，少なくと も本実験では鋳塊への蓄熱速度やスラグ浴表面から大気 への伝熱速度はきわめて小さいと考えられる。

\section{$3 \cdot 1 \cdot 1$ 伝熱速度}

定常融解期に拈ける伝熱経路を便宜上 Fig. 5 のよう に表すと，スラグ浴領域，メタル浴円柱部領域，凝固鋳 塊領域，凝固鋳塊底部およびスラグ浴表面から冷却水一 の伝熱速度 $q_{\mathrm{s}-\mathrm{w}}, q_{\mathrm{m}-\mathrm{w}}, q_{\mathrm{i}-\mathrm{w}}, q_{\mathrm{b}-\mathrm{w}}, q_{\mathrm{rad}-\mathrm{w}}(\mathrm{cal} / \mathrm{s})$ は，各領域に持汁る冷却水の温度上昇より，(5)'式と同
様の式によつて計算することができる。

鋳型内の各温度測定位置における融解過程中の温度変

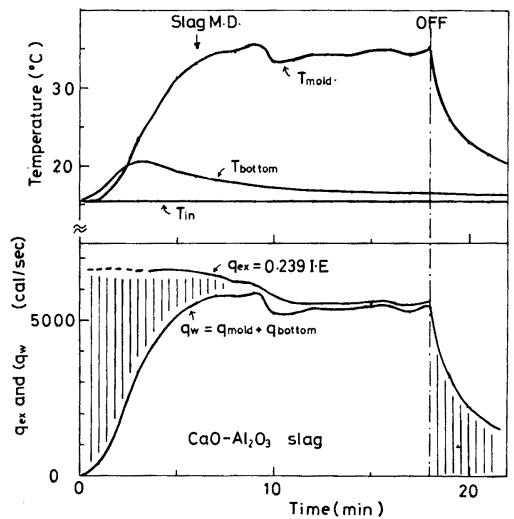

Fig. 4. Transitional changes in the temperatures of cooling water in mold and base plate, $T_{\text {in }}, T_{\text {mold }}$, and $T_{\text {bottom }}$, and input and output heat transfer rates, $\mathrm{q}_{\mathrm{ex}}, \mathrm{q}_{\mathrm{w}}$, during remelting.

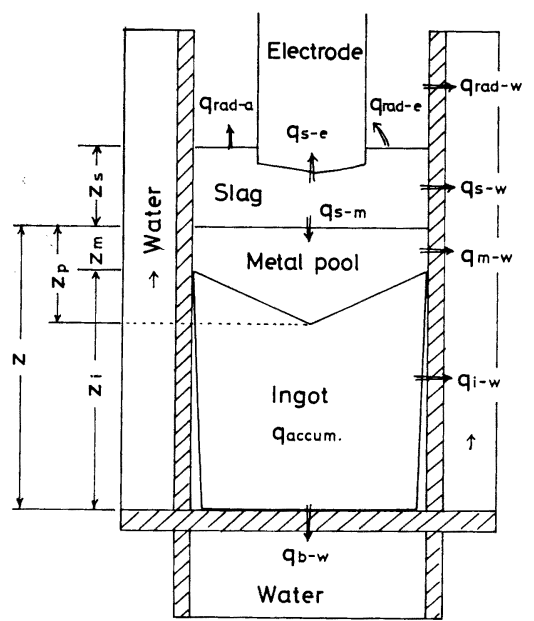

Fig. 5. Schematic diagram of heat flow during ESR. 
化の一例を示すと Fig. 6 のと打りである.これより， 任意のスラグ浴一メタル浴界面位置, たとえば界面がある 高さ $z$ に達したとき，その場合の鋳型および冷却水中の 高さ方向の温度分布を容易に知ることができる.なお， $z$ は融解終了時の鋳塊高さ, 電極降下量および Fill ratio (電極/鋳型断面比) から計算することができる.

スラグの成分組成を変えた場合の鋳型および冷却水中 の温度分布の一例を示すと Fig. 7 のとおりである. 冷 却水は上方に向かつて流れており，その温度はメタル浴 円柱部下端に相当する仕置から急激に上昇する，鋳型壁 温度はスラグ浴ーメタル浴界面近傍に相当する領域で最 も高く，スラグ浴表面に向かつて低下する傾向を示す. 冷却水出口水温, 鋳型壁温度はともにフッ化物系スラグ

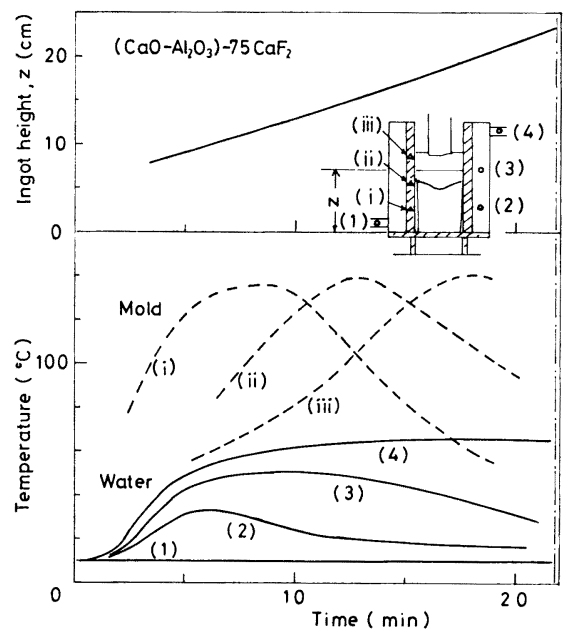

Fig. 6. Typical transitional changes of the temperature of mold and cooling water at various positions during remelting.
の場合のほうが，酸化物系スラグの場合よりも高いな お鋳型壁の最高温度は実験条件により若干異なるが，

$120 \sim 140^{\circ} \mathrm{C}$ である。

このよらな温度分布図から各領域における冷却水の温 度上昇を求め，伝熱速度を計算した結果を示すと Table 2 のとおりである。 $q_{\mathrm{i}-\mathrm{w}}, q_{\mathrm{b}-\mathrm{w}}$ はスラグの成分組成お よび融解速度による依存性が小さくこれは鋳塊-鋳型間 に空隙が生じ，放射伝熱が支配的になるためと考えられ る.これに対し $q_{\mathrm{m-w}}, q_{\mathrm{rad- \textrm {w }}}$ はいずれも久ラグ中の $\mathrm{CaF}_{2}$ 成分の増加とともに著しく大きくなり，また投入 電力の増加とともに大きくなる.なお，スラグ浴一メタル 浴間の伝熱速度 $q_{\mathrm{s}-\mathrm{m}}$ は，本実験では前述のように䇥常 融解期の鋳塊への蓄熱が汪とんどないので，人タル浴お よび鋳塊から冷却水への伝熱速度の和 $\left(q_{\mathrm{m}-\mathrm{w}}+q_{\mathrm{i}-\mathrm{w}}+\right.$ $\left.q_{\mathrm{b}-\mathrm{w}}\right)$ に等しく, $\mathrm{CaF}_{2}$ 量とともに増加する. スラグ浴 における発熱速度に対する各領域を通しての伝熱速度の 割合を示すと Fig. 8 のとおりである.この結果によれ ばスラグ浴領域における伝熱比が最も大きく，40～50\%

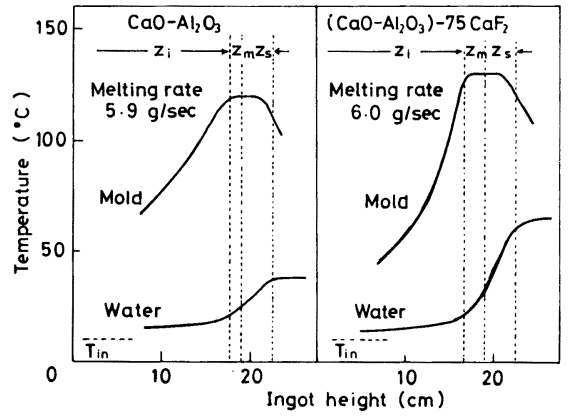

Fig. 7. Effect of slag composition on the temperature distributions of mold cooling water.

Table 2. Melting condition and heat transfer rate.

\begin{tabular}{|c|c|c|c|c|c|c|}
\hline & Salg & $\mathrm{CaO}-\mathrm{Al}_{2} \mathrm{O}_{3}$ & $\begin{array}{l}\left(\mathrm{CaO}-\mathrm{Al}_{2} \mathrm{O}_{3}\right) \\
-25 \mathrm{CaF}_{2}\end{array}$ & $\begin{array}{c}\left(\mathrm{CaO}-\mathrm{Al}_{2} \mathrm{O}_{3}\right) \\
-50 \mathrm{CaF}_{2}\end{array}$ & $\begin{array}{c}\left(\mathrm{CaO}-\mathrm{Al}_{2} \mathrm{O}_{3}\right) \\
-75 \mathrm{CaF}_{2}\end{array}$ & $\begin{array}{c}\left(\mathrm{CaO}-\mathrm{Al}_{2} \mathrm{O}_{3}\right) \\
-25 \mathrm{CaF}_{2}\end{array}$ \\
\hline \multirow{3}{*}{ 占: } & Current, $\quad I(\mathrm{~A})$ & 884 & 934 & 1293 & 1512 & 1154 \\
\hline & Voltage, $\quad E(\mathrm{~V})$ & 26.4 & 25.9 & 27.5 & 28.2 & 28.7 \\
\hline & Melting rate $(\mathrm{g} / \mathrm{s})$ & 5.9 & 5.9 & 5.8 & 6.0 & 7.0 \\
\hline \multirow{4}{*}{ 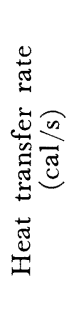 } & $q_{\mathrm{ex}}$ & 5580 & 5780 & 8500 & 10190 & 7920 \\
\hline & $\begin{array}{l}q_{\mathrm{i}-\mathrm{w}} \\
q_{\mathrm{m}-\mathrm{w}} \\
q_{\mathrm{s}-\mathrm{w}} \\
q_{\mathrm{rad}-\mathrm{w}}\end{array}$ & $\begin{array}{r}1600 \\
830 \\
2200 \\
370\end{array}$ & $\begin{array}{r}1430 \\
1100 \\
2330 \\
610\end{array}$ & $\begin{array}{r}1230 \\
1800 \\
4180 \\
\\
860\end{array}$ & $\begin{array}{ll}1 & 270 \\
2 & 130 \\
5 & 120 \\
1 & 280\end{array}$ & $\begin{array}{r}1450 \\
1410 \\
3940 \\
750\end{array}$ \\
\hline & $q_{\mathrm{b}-\mathrm{w}}$ & 300 & 280 & 300 & 300 & 330 \\
\hline & $q_{\mathrm{s}-\mathrm{m}} *$ & 2730 & 2810 & 3330 & 3700 & 3190 \\
\hline
\end{tabular}


Table 3. Overall heat transfer coefficient.

\begin{tabular}{|c|c|c|c|c|c|}
\hline \multirow{2}{*}{ Slag } & \multirow{2}{*}{$\underset{(\mathrm{g} / \mathrm{s})}{\text { Melting rate }}$} & \multicolumn{4}{|c|}{ Overall heat transfer coef. $\left(\mathrm{cal} / \mathrm{cm}^{2} \cdot \mathrm{s} \cdot \mathrm{deg}\right)$} \\
\hline & & Slag bath-Water & $\begin{array}{l}\text { Metal-bath } \\
\text {-Water }\end{array}$ & Ingot-Water & $\begin{array}{l}\text { Ingot bottom } \\
\text {-Water }\end{array}$ \\
\hline $\begin{array}{l}\mathrm{Cal}-\mathrm{Al}_{2} \mathrm{O}_{3} \\
\left(\mathrm{CaO}-\mathrm{Al}_{2} \mathrm{O}_{3}\right)-25 \mathrm{CaF}_{2} \\
\left(\mathrm{CaO}-\mathrm{Al}_{2} \mathrm{O}_{3}\right)-50 \mathrm{CaF}_{2} \\
\left(\mathrm{CaO}-\mathrm{Al}_{2} \mathrm{O}_{3}\right)-75 \mathrm{CaF}_{2}\end{array}$ & $\begin{array}{l}5.9 \\
5.9 \\
5.8 \\
6.0\end{array}$ & $\begin{array}{l}0.014 \\
0.014 \\
0.026 \\
0.031\end{array}$ & $\begin{array}{l}0.015 \\
0.018 \\
0.019 \\
0.022\end{array}$ & $0.003 \sim 0.005$ & $0.01 \sim 0.02$ \\
\hline$\left(\mathrm{CaO}-\mathrm{Al}_{2} \mathrm{O}_{3}\right)-25 \mathrm{CaF}_{2}$ & 7.0 & 0.023 & 0.019 & & \\
\hline
\end{tabular}

を占めているが，スラグの成分組成の影響もかなり大き い.フッ化物系スラグに比べて酸化物系スラグはスラグ 浴での熱損失が少なく, 熱が電極の融解に有効に消費さ れることを裏づけている。

\section{$3 \cdot 1 \cdot 2$ 総括伝熱係数}

スラグ浴，メタル浴円柱部扣よび凝固鋳塊と鋳型内冷 却水間, 鋳塊と炉底盤内冷却水間の総括伝熱係数 $U_{\mathrm{s}-\mathrm{w}}$, $U_{\mathrm{m}-\mathrm{w}}, U_{\mathrm{i}-\mathrm{w}}, U_{\mathrm{b}-\mathrm{w}},\left(\mathrm{cal} / \mathrm{cm}^{2} \cdot \mathrm{s} \cdot \mathrm{deg}\right)$ を $(6) \sim(9)$ 式 より計算した結果を示すと Table 3 のとおりである.

$$
\begin{aligned}
& U_{\mathrm{s}-\mathrm{w}}=q_{\mathrm{s}-\mathrm{w}} / 2 \pi r_{0} z_{\mathrm{s}}\left(T_{\mathrm{s} 1}-T_{\mathrm{w}}\right) \cdots \\
& U_{\mathrm{m}-\mathrm{w}}=q_{\mathrm{m}-\mathrm{w}} / 2 \pi r_{0} z_{\mathrm{m}}\left(T_{\mathrm{m}}-T_{\mathrm{w}}^{\prime}\right) \\
& U_{\mathrm{i}-\mathrm{w}}=q_{\mathrm{i}-\mathrm{w}} / 2 \pi r_{0} z_{\mathrm{i}}\left(T_{\mathrm{i}}-T_{\mathrm{w}}^{\prime \prime}\right) \\
& U_{\mathrm{b}-\mathrm{w}}=q_{\mathrm{b}-\mathrm{w}} / \pi r_{0}^{2}\left(T_{\mathrm{i}(\mathrm{b})}-T_{\mathrm{w}(\mathrm{b})}\right)
\end{aligned}
$$

ここで， $r_{\mathbf{0}}$ は鋳型半径 $(\mathrm{cm}) ， z_{\mathrm{s}} ， z_{\mathrm{m}} ， z_{\mathrm{i}}$ はそれぞれ スラグ浴深さ，メタル浴円柱部高さおよび凝固鋳塊高さ $(\mathrm{cm}), T_{\mathrm{s} 1}, T_{\mathrm{m}}, T_{\mathrm{i}}, T_{\mathrm{i}(\mathrm{b})}$ はそれぞれスラグ浴温度, メタル浴温度，凝固鋳塊側面温度および 鋳塊底部温度
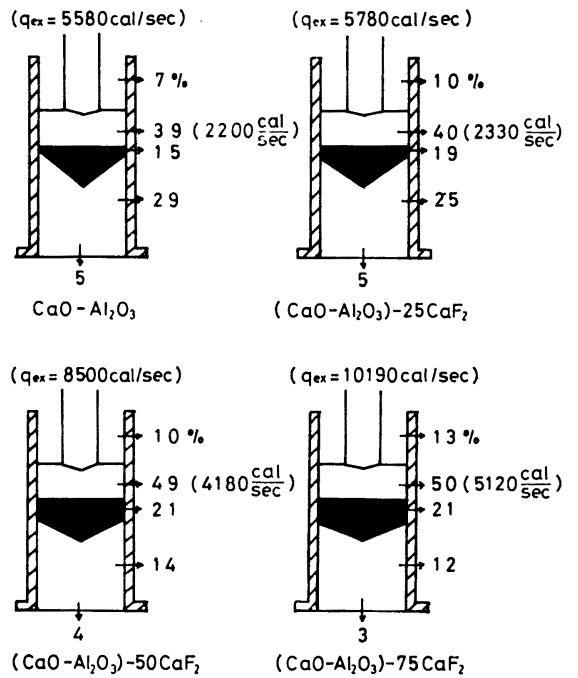

Fig. 8. Effect of slag composition on the heat balance in remelting at steady state by $80 \mathrm{~mm} \phi$ ESR furnace (Melting rate : $5.8-6.0 \mathrm{~g} / \mathrm{s})$. $\left({ }^{\circ} \mathrm{C}\right), T_{\mathrm{w}}, T_{\mathrm{w}}^{\prime}, T_{\mathrm{w}}^{\prime \prime}, T_{\mathrm{w}(\mathrm{b})}$ はそれぞれの領域にお打る 冷却水の温度 $\left({ }^{\circ} \mathrm{C}\right)$ である.な拈 $z_{\mathrm{m}}$ は鋳塊のサルフ ア・プリントの結果より求め, $T_{\mathrm{m}}$ は $T_{\mathrm{s} 1}$ とメタル融 点との平均温度，また $T_{\mathrm{i}}$ はメタル融点と $T_{\mathrm{i}(\mathrm{b})}$ との平 均温度を用いた。 $T_{\mathrm{i}(\mathrm{b})}$ は，スタート板に熱電対を埋め 込んで測温した結果によれば，定常融解期ではほぼ400 ${ }^{\circ} \mathrm{C}$ であり，鋳塊一炉底盤間には接触伝熱抵抗があると考 えられる、 $U_{\mathrm{s}-\mathrm{w}}$ は, $\mathrm{CaF}_{2}$ 量抢よび融解速度の増加と ともに大きくなり，これはスラグ殸の熱伝導率と密接に 関連すると考えられる. メタル浴円柱部では, スラグ浴 で形成された凝固スラグ殸がメタル浴に近づくにしたが つて再融解し，スラグ殸の厚さが薄くなるため, 総括伝 熱係数に対するスラグの成分組成の影響は小さくなる.

$U_{\mathrm{i}-\mathrm{w}}$ は鋳型テーパのとりかたや鋳型との接触状態に左 右されるが，本実験では $U_{\mathrm{i}-\mathrm{w}}$ はメタル浴円柱部の総括 伝熱係数に比べて 1 桁小さい. また $U_{\mathrm{b}-\mathrm{w}}$ は $U_{\mathrm{i}-\mathrm{w}}$ よ りは大きいが，これは鋳塊底部と炉底盤が直接に接触し， ているためと考えられる。これらの值は梅田 ${ }^{15)}$ が ESR 鋳塊の凝固計算にあたつて推定した伝熱係数より若干小 さく，ほぼ同径の鋳型を用いて伝熱挙動を測定した

MITCHELL ら 1$)$ の結果に近い.

\section{$3 \cdot 2$ スラグ款の有効熱伝導率}

スラグ浴-鋳型内泠却水間の伝熱挙動は前述のように スラグ殸の 熱伝導率と密接に関係する、 $\mathrm{CaO}-\mathrm{Al}_{2} \mathrm{O}_{3}$ $\mathrm{CaF}_{2}(40 / 17 / 43)$ 共晶組成のスラグ殼の有効熱伝導率 $k_{\mathrm{s}}$ はFig. 9 に示すとおりであり, 温度とともに増加する. これについてはスラグ殸には光の透過性があり，高温に おいてとくに放射による伝熱の寄与が現れたものと考え られる、 $\mathrm{CaO}-\mathrm{Al}_{2} \mathrm{O}_{3}(50 / 50)$ に $\mathrm{CaF}_{2}$ を添加した場合 のスラグ殼の有効熱伝導率 $k_{\mathrm{s}}$ とスラグ浴-銅管内冷却水 間の総括伝熱係数 $U_{\mathrm{r}_{2}}$ の值を示すと Fig. 10 のとおり であり， $k_{\mathrm{S}}$ は $\mathrm{CaF}_{2}$ 量とともに大きくなり，とくに $\mathrm{CaF}_{2}$ が $75 \%$ 以上ではかなり著しく増大する。いつぽ 万， $U_{\mathrm{r}_{2}}$ は $k_{\mathrm{s}}$ 汪ど大きな変化はないが，これは Table 4 に示したようにスラグ中の $\mathrm{CaF}_{2}$ 量が多くなるほど銅 壁-スラグ殸間の伝熱抵抗が大きくなるためである．測 
Table 4. Thermal resistances at various interfaces and regions between slag bath and cooling water. $(\mathrm{s} \cdot \mathrm{deg} / \mathrm{cal})$

\begin{tabular}{|c|c|c|c|c|c|c|}
\hline $\begin{array}{|rr|}\text { Thermal } & \begin{array}{l}\text { resis- } \\
\text { tance }\end{array} \\
\text { Slag } & \\
\end{array}$ & Total & $\begin{array}{l}\text { Slag bath } \\
\text {-Slag crust }\end{array}$ & Slag crust & $\begin{array}{l}\text { Slag crust } \\
\text {-Cu pipe }\end{array}$ & Cu pipe & $\begin{array}{l}\text { Cu pipe } \\
\text {-Water }\end{array}$ \\
\hline $\mathrm{CaO}-\mathrm{Al}_{2} \mathrm{O}_{3}$ & $35 \cdot 4$ & $\begin{array}{c}4.6 \\
(13)\end{array}$ & $\begin{array}{l}28.5 \\
(79)\end{array}$ & $\begin{array}{r}0.7 \\
(2)\end{array}$ & $\begin{array}{l}0.01 \\
(\simeq 0)\end{array}$ & $\begin{array}{r}2.2 \\
(6)\end{array}$ \\
\hline $\begin{array}{l}\left(\mathrm{CaO}-\mathrm{Al}_{2} \mathrm{O}_{3}\right) \\
-50 \mathrm{CaF}_{2}\end{array}$ & 30.3 & $\begin{array}{l}3.6 \\
(12)\end{array}$ & $\begin{array}{l}14.3 \\
(46)\end{array}$ & $\begin{array}{l}10.9 \\
(36)\end{array}$ & $\begin{array}{c}0.01 \\
(\simeq 0)\end{array}$ & $\begin{array}{l}1.7 \\
(6)\end{array}$ \\
\hline $\mathrm{CaF}_{2}$ & 21.7 & $\begin{array}{l}2.9 \\
(13)\end{array}$ & $\begin{array}{c}5.4 \\
(25)\end{array}$ & $\begin{array}{l}12.0 \\
(56)\end{array}$ & $\begin{array}{c}0.01 \\
(\simeq 0)\end{array}$ & $\begin{array}{l}1.3 \\
(6)\end{array}$ \\
\hline
\end{tabular}

Note : Figures in parenthesis mean the proportion of heat resistance at each part to total heat resistance (\%)

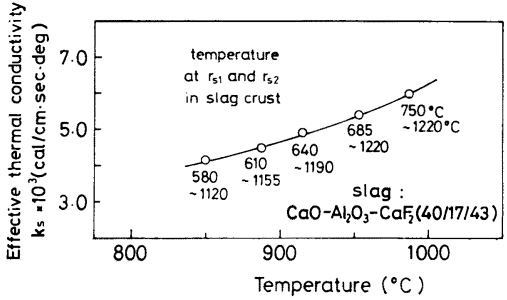

Fig. 9. Dependence of the effective thermal conductivity of slag crust on temperature.

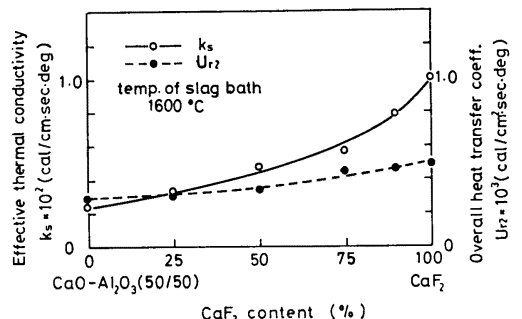

Fig. 10. Effect of slag composition on effective thermal conductivity of slag crust and overall heat-transfer coefficient.
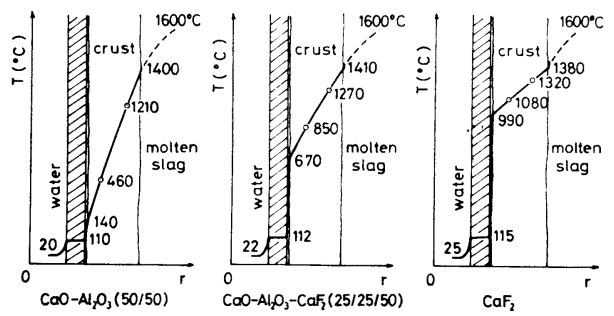

Fig. 11. Effect of slag composition on the temperature gradient between slag bath and cooling water.

定值から求めた温度勾配を示すと Fig. 11 のとおりであ り， $k_{\mathrm{s}}$ の大きいスラグほどスラグ殼内の温度勾配が小 さく,銅壁-スラグ殸界面に拈ける温度差が大きくなる. $\mathrm{CaF}_{2}$ の場合，スラグ殸-銅管壁間に大きな温度差が認め
られるが，これは $\mathrm{CaF}_{2}$ を用いた MitchelL ら8)の結 果とよく一致している. $\mathrm{CaO}-\mathrm{Al}_{2} \mathrm{O}_{3}$ においてはスラグ 殸での温度勾配が大きく, 温度差の小さいことが特長で ある。

本実験で求めた有効熱伝導率に対する相対䛊差につい て，伝熱速度 $q$ の相対䛊差が約 $3 \%$ あり，その他の測定 䛊差は浸漬深さの測定䛊差を $\pm 1 \mathrm{~mm}$, 温度測定䛊差を $\pm 5^{\circ} \mathrm{C}$ ，測定位㯰の設定䛊差を $\pm 0.5 \mathrm{~mm}$ と見積もると， 全相対誤差は $20 \sim 25 \%$ となる.このうちスラグ款の温 度測定位置による誤差の寄与が最も大きく $1 / 2$ 以上を占 めている。

\section{3 融解速度と伝熱挙動}

電極の融解速度は電極近傍のスラグ浴温度に依存する が10)，このスラグ浴温度は投入電力によつて一義的に 決まらず,スラグ浴からの伝熱特性に大きく左右される.

そこでスラグ浴内の温度分布におよぼすスラグの成分 組成の影響を明らかにするため, タングステンーレニウム $(\mathrm{W} 5 \% \mathrm{Re} / \mathrm{W} 26 \% \mathrm{Re})$ 熱電対扣よびボロンナイトライド 保護管を用いて, 鋳型壁より $3 \mathrm{~mm}$ 離れた位置, 電極-鋳 型壁の中間および電極より $3 \mathrm{~mm}$ 離れた位置における高 さ方向の温度を測定した．その結果を示すとFig. 12 の と拈りであり，( $\left.\mathrm{CaO}-\mathrm{Al}_{2} \mathrm{O}_{3}\right)-50 \mathrm{CaF}_{2}$ スラグではスラグ

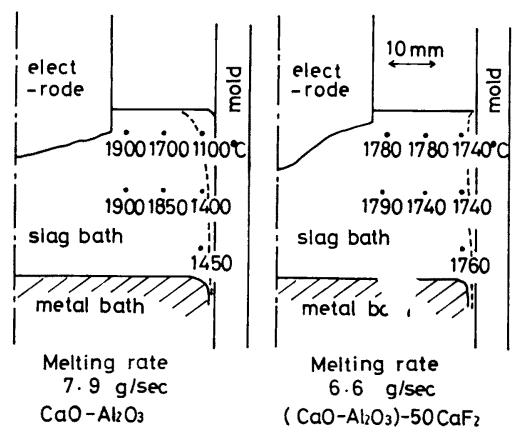

Fig. 12. Temperature distributions in slag bath. 
款近傍までスラグ浴内温度はほぼ均一となり，川上ら²) の $\mathrm{CaF}_{2}-\mathrm{Al}_{2} \mathrm{O}_{3}$ 系スラグにお污る測定結果之同様の傾向 を示すのに対して， $\mathrm{CaO}-\mathrm{Al}_{2} \mathrm{O}_{3}$ スラグではスラグ殸近 傍においてフッ化物系スラグよりも低い温度を示す。 こ れはフッ化物系スラグのほらが, スラグの粘度が小さく, また電気抵抗が小さく16), 同一融解速度をえるために必 要な投入電力も大きいため，スラグ浴の流動速度が大き くなり45), スラグ浴内の温度が均一化しやすいためであ ると考えられる。

なお本実験では，スラグ浴温度を電極-鋳型壁の中間, 深さ $1 / 2$ の位置で測定しているが，電極の融解速度を支 配する電極近傍の温度との間にそら大きな差はない.

いつぽう, ESR 法においてはスラグ浴域で形成される スラグ殸の厚さは $1750 \sim 1800^{\circ} \mathrm{C}$ に扔いて 0.5 2 $\mathrm{mm}$ 程度であり，スラグ殸の温度勾配を直接測定することは 困難である、したがつて, 融解中のスラグ浴一鋳型内冷却 水間の伝熱速度, スラグ浴温度, スラグ殸厚さおよび前 記実験で求めたスラグ殸の有効熱伝導率を用いて，スラ グ浴-鋳型冷却水間の温度勾配，スラグ浴-スラグ殼間の 伝熱係数 $h_{3}\left(\mathrm{cal} / \mathrm{cm}^{2} \cdot \mathrm{s} \cdot \mathrm{deg}\right)$ および鋳型壁-冷却水間の 伝熱係数 $h_{1}\left(\mathrm{cal} / \mathrm{cm}^{2} \cdot \mathrm{s} \cdot \mathrm{deg}\right)$ を求めた結果を示すと Fig. 13 のとおりである. $h_{3}$ は $\mathrm{CaF}_{2}$ 量とともに增加するが， これはスラグ浴の流動速度が大きくなることに対応して いる．また， $h_{1}$ は乱流伝熱の式17)から計算される伝熱係 数 $\left(h_{1}=0.001 \mathrm{cal} / \mathrm{cm}^{2} \cdot \mathrm{s} \cdot \mathrm{deg}\right)$ よりはるかに大きいが， これはスラグ浴およびメタル浴に相当する領域の鋳型壁 冷却水中に著しい気泡の発生が認められることから, 鋳 型-冷却水間の伝熱形態が核沸騰伝熱であるためと考え られる・スラグ浴一冷却水間の各界面および領域の伝熱 抵抗を求めると Table 5 のと扣りである. 酸化物系ス ラグではスラグ殸領域の伝熱抵抗が $1 / 2$ 以上を占めてい るが,フッ化物系スラグではスラグ殼-鋳型間の温度差が 大きくなり，この部分の全伝熱抵抗に占める割合が増大 する傾向にある．この温度差はスラグ殸と鋳型壁との接 触状態に密接に関係しており，フッ化物系スラグでは凝 固収縮および固体の熱膨張率が大さい18)ため空陌を形成

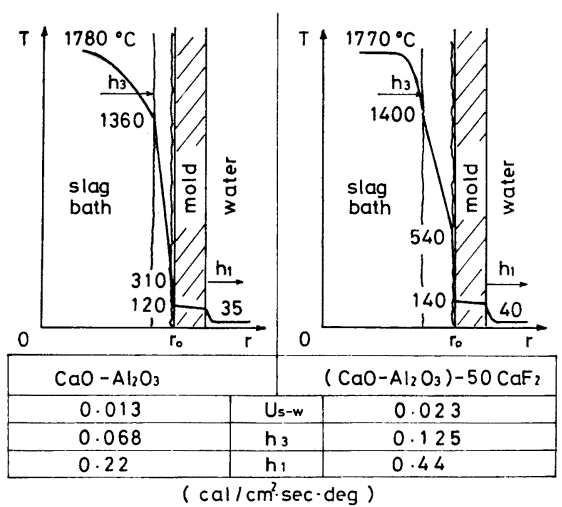

Fig. 13. Effect of slag composition on the temperature gradient between slag bath and cooling water, overall heat transfer coefficient $U_{\mathrm{s}-\mathrm{w}}$, and heat transfer coefficients at slag bath-slag crust, $h_{3}$, and at moldcooling water, $h_{1}$.

しやすく，伝熱抵抗が大きくなることは容易に推察され る.

定常融解期においては， $q_{\mathrm{ex}}$ に対する $q_{\mathrm{s}-\mathrm{w}}$ の割合を $f$ と拝くと $q_{\mathrm{s}-\mathrm{w}}$ と $f$ の間には $(10)$ 式の関係が成立 する.

$$
\begin{aligned}
q_{\mathrm{s}-\mathrm{w}} & =f q_{\mathrm{ex}} \\
& =2 \pi r_{0} z_{\mathrm{s}} U_{\mathrm{s}-\mathrm{w}}\left(T_{\mathrm{s} 1}-T_{\mathrm{w}}\right)
\end{aligned}
$$

いつ核う, 電極の融解速度 $V(\mathrm{~g} / \mathrm{s})$ は電極近傍スラグ浴 温度に比例するが10)，本実験では前述のよらに電極表面 からの放熱速度は小さいので, スラグ浴-電極界面におけ る伝熱だけを考えると $V$ と $T_{\mathrm{s} 1}$ の関係は (11) 式によ り表される。

$$
V\left(H_{\mathrm{mp}}-H_{\mathrm{RT}}\right)=h_{\mathrm{S}-\mathrm{e}} S\left(T_{\mathrm{s} 1}-T_{\mathrm{mp}}\right)
$$

ここで, $H_{\mathrm{mp}}-H_{\mathrm{RT}}$ は単位質量当たりの電極材の融解に 要する熱量 ${ }^{19)}(\mathrm{cal} / \mathrm{g}), h_{\mathrm{S}-\mathrm{e}}$ はスラグ浴-電極間伝熱係数 $\left(\mathrm{cal} / \mathrm{cm}^{2} \cdot \mathrm{s} \cdot \mathrm{deg}\right), S$ は電極一スラグ浴界面積 $\left(\mathrm{cm}^{2}\right), T_{\mathrm{mp}}$ は電極材の融点 $\left({ }^{\circ} \mathrm{C}\right)$ である. 2,3 のスラグおよび鋼に ついて (11) 式より $h_{\mathrm{S}-\mathrm{e}}$ を求めると $0.39 \sim 0.48 \mathrm{cal} /$ $\mathrm{cm}^{2} \cdot \mathrm{s} \cdot \mathrm{deg}$ 程度となる。また, 電力原単位 $P(\mathrm{~W} \cdot \mathrm{s} / \mathrm{g})$ は

\begin{tabular}{|c|c|c|c|c|c|c|}
\hline $\begin{array}{c}\text { Thermal resist- } \\
\text { ance } \\
\text { Slag }\end{array}$ & Total & $\begin{array}{l}\text { Slag bath } \\
\text {-Slag crust }\end{array}$ & Slag crust & $\begin{array}{l}\text { Slag crust } \\
\text {-Mold }\end{array}$ & Mold & Mold-Water \\
\hline $\mathrm{CaO}-\mathrm{Al}_{2} \mathrm{O}_{3}$ & 0.81 & $\begin{array}{l}0.19 \\
(23)\end{array}$ & $\begin{array}{c}0.48 \\
(59)\end{array}$ & $\begin{array}{l}0.09 \\
(11)\end{array}$ & $\begin{array}{r}0.007 \\
(1)\end{array}$ & $\begin{array}{c}0.04 \\
(5)\end{array}$ \\
\hline $\begin{array}{l}\left(\mathrm{CaO}-\mathrm{Al}_{2} \mathrm{O}_{3}\right) \\
-50 \mathrm{CaF}_{2}\end{array}$ & 0.43 & $\begin{array}{l}0.09 \\
(21)\end{array}$ & $\begin{array}{l}0.21 \\
(49)\end{array}$ & $\begin{array}{l}0.10 \\
(23)\end{array}$ & $\begin{array}{r}0.007 \\
(2)\end{array}$ & $\begin{array}{c}0.02 \\
(5)\end{array}$ \\
\hline
\end{tabular}

Table 5. Thermal resistances at various interfaces and regions between slag bath and cooling water in ESR. ( $\mathrm{s} \cdot \mathrm{deg} / \mathrm{cal})$

Note : Figures in parenthesis mean the proportion of heat resistance at each part to total heat resistance (\%) 
融解速度とスラグ浴への投入電力から (12) 式で表され, (4)，(10) および (11) 式を代入すると（13）式となる.

$$
\begin{gathered}
P=I E / V \cdots \\
P=\frac{U_{\mathrm{s}-\mathrm{w}}\left(T_{\mathrm{s} 1}-T_{\mathrm{w}}\right)}{h_{\mathrm{s}-\mathrm{e}} S\left(T_{\mathrm{s} 1}-T_{\mathrm{mp}}\right)} \cdot \frac{\left(H_{\mathrm{mp}}-H_{\mathrm{RT}}\right) 2 \pi r_{0} z_{\mathrm{s}}}{0.239 f}
\end{gathered}
$$

$360 \mathrm{~mm} \phi$ ESR 炉に执いて, $\mathrm{CaO}-\mathrm{Al}_{2} \mathrm{O}_{3}$ 扩よび $(\mathrm{CaO}-$ $\left.\mathrm{Al}_{2} \mathrm{O}_{3}\right)-50 \mathrm{CaF}_{2}$ スラグを用いて融解を行つた結果 ${ }^{10)} に$ よると，電力原単位はそれぞれ $1.32 \mathrm{kWh} / \mathrm{kg}$ および $1.66 \mathrm{kWh} / \mathrm{kg}$ である、いつぽう，本実験でえられた $U_{\mathrm{S}-\mathrm{w}}, h_{\mathrm{S}-\mathrm{e}}$ 拈よび $f$ がそのまま大型炉にも適用できる と仮定して (13) 式から電力原単位を求めると, $\mathrm{CaO}$ $\mathrm{Al}_{2} \mathrm{O}_{3}$ 打よび $\left(\mathrm{CaO}-\mathrm{Al}_{2} \mathrm{O}_{3}\right)-50 \mathrm{CaF}_{2}$ スラグについてそ れぞれ $1.04 \mathrm{kWh} / \mathrm{kg}$ および $1.47 \mathrm{kWh} / \mathrm{kg}$ となる.

(13) 式から求めた電力原単位は実際の電力原単位に比べ て小さいが，これは大型 ESR 炉に和ける $U_{\mathrm{S}-\mathrm{w}}, f$ な どの值が小型炉の場合と異なるためと考えられる。そこ で $\mathrm{CaO}-\mathrm{Al}_{2} \mathrm{O}_{3}$ 㧊よび $\left(\mathrm{CaO}-\mathrm{Al}_{2} \mathrm{O}_{3}\right)-50 \mathrm{CaF}_{2}$ スラグ の場合について電力原単位の比をとると, 実操業で 0.79 であるのに対し，(13) 式によると0.71 であり，湆济対 応している. 実際の伝熱係数は炉の大きさや操業条件に よつて異なるが，少なくとも伝熱挙動のスラグの成分組 成による違いについては大型炬も小型炉の場合之同様で あると考兄られる。

\section{4 鋳塊品質と伝熱挙動}

鋳塊品質がメタル浴形状に著しく左右されるため, こ れまでにもメタル浴形状と操業条件との関係2) 20), メ夕 儿浴形状の伝熱解析 ${ }^{15}$ についてかなりの検討が行われて いる.ところがィタル浴形状の伝熱解析に関しては，た いていの場合, スラグ浴一メタル浴界面の温度は一様であ るとして取り扱われている.フッ化物系スラグの場合に はスラグ浴の温度分布が均一なため問題はないが，酸化 物系スラグの場合にはスラグ浴内の温度分布も考虑する 必要がある.

種々のスラグを用いて融解した場合の融解速度，スラ グ浴一メタル浴界面を通しての伝熱速度 $q_{\mathrm{s}-\mathrm{m}}$ と, サル ファ・プリントから求めたメタル浴深さ $z_{\mathrm{p}}$ 打よびメタ 几浴円柱部高さ $z_{\mathrm{m}}$ との関係を示すと Fig. 14 のとおり である．Fig．14a）に示したように $z_{\mathrm{p}}$ はスラグの成分 組成に関係なく融解速度とともに增加するのに対し， $z_{\mathrm{m}}$ と融解速度との関係はばらつきがあり明らかでない。い つぽう，Fig. 14b) に示したように， $z_{\mathrm{p}}$ は $q_{\mathrm{s}-\mathrm{m}}$ に対 し一義的に定まらないのに対し， $z_{\mathrm{m}}$ は $q_{\mathrm{s}-\mathrm{m}}$ に比例す る.このことは前記のように $q_{\mathrm{s}-\mathrm{m}}$ はスラグ中の $\mathrm{CaF}_{2}$ 量とともに大きくなること，また同一融解速度ではスラ

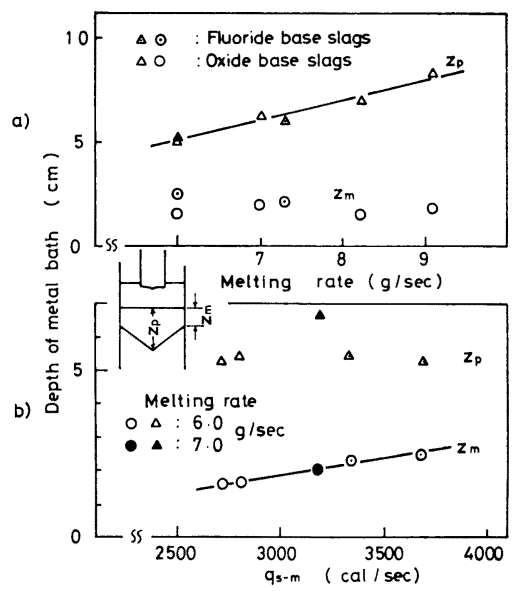

Fig. 14. Relation between the depth of metal bath and melting rate (a) and heat transfer rate through the interface of slag bathmetal bath (b).

グ浴温度はスラグの成分組成によらずほぼ同一であるこ そ10)を考学ると， $z_{\mathrm{p}}$ は電極直下拉よび近傍のスラグ浴領 域からのメタル浴への伝熱速度に依存するのに対し， $z_{\mathrm{m}}$ は鋳型近傍に括けるスラグ浴領域からメタル浴への伝熱 速度に依存することを意味している。すなわちフッ化物 系スラグのほうが鋳型近傍まで高温域にあるため，鋳型 近傍に扣けるメタル浴一の伝熱速度が大きくなる。本実 験で得られたスラグの成分組成とメタル浴形状の関係は $690 \mathrm{~mm} \phi$ 大型 ESR 炉でスラグの成分組成の影響を調

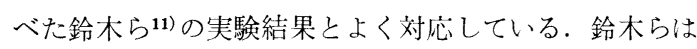
メタル浴形状とスラグの成分組成の関係について, 酸化 物系スラグはフッ化物系スラグよりスラグ殸が薄いた め，鋳型への伝熱速度が大きくなり，ィタル浴円柱部が 小さくなると推定しているが，本実験結果に上れば，酸 化物系スラグはスラグ款近傍のスラグ浴領域からのメタ ル浴への伝熱速度が小さいため，メタル浴円柱部が小さ くなると考える汪らが妥当である.

メタル浴とくに凝固前面の形状は, 一般に $z_{\mathrm{p}}$ と $z_{\mathrm{m}}$ の関係により定まる．酸化物系スラグでは $z_{\mathrm{p}}$ に対し $z_{\mathrm{m}}$ が小さいため，凝固前面の傾きが大きくなる傾问を 示し，デンドライトの成長方向を示す水平面に対する傾 きは小さくなる．また酸化物系スラグではフッ化物系ス ラグに比べて小さい投入電力で人きい融解速度が得られ るため，とくに鋳塊表層部において冷却速度が大きくな る.したがつて鋳塊表層部の凝固組織の緻密性が要求さ れるロール鋼などには有利である.鋳塊表面欠陥の一つ である 2 重肌は，スラグ殸の破壞に伴う溶鋼の流出によ

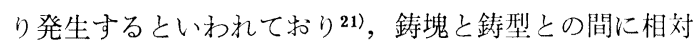


的な動きのある場合，たとえば鋳型引き上げ方式や鋳塊 引き下げ方式の場合に，ィタル浴円柱部が大きいと起こ りやすい.したがつて，このような場合にも酸化物系ス ラグのほらが有利である。

\section{4. 結言}

ESR におけるスラグ浴-鋳塊一鋳型間の伝熱挙動にお。 よぼすスラグの成分組成の影響を明らかにするため, $\mathrm{CaO}-\mathrm{Al}_{2} \mathrm{O}_{3}$ および $\mathrm{CaO}-\mathrm{Al}_{2} \mathrm{O}_{3}-\mathrm{CaF}_{2}$ 系スラグを用い て実験を行い，鋳型内の温度分布括よび冷却水への伝熱 速度の 測定から熱の移動経路および総括伝熱係数を求 め,さらに伝熱現象に密接に影響を与えるスラグ殸の有 効熱伝導率を测定した.

その結果を要約すると次のとおりである.

（1）定常融解期に扮ける冷却水一の伝熱速度は，又 ラグ浴領域からの割合がもつとも大きく，酸化物系スラ グではスラグ浴に扣ける発熱速度の約 $40 \%$, フッ化物系 スラグではほぼ 50\% に達する。

(2) スラグ浴-鋳型内冷却水間の総括伝熱係数は $0.014 \sim 0.03 \mathrm{cal} / \mathrm{cm}^{2} \cdot \mathrm{s} \cdot \mathrm{deg}$ 程度であり,スラグの成分組 成による影響が大きいのに対し，メタル浴円柱部-鋳型内 冷却水間の総括伝熱係数におよぼすスラグの成分組成の 影響は小さく，いずれのスラグに拈いてもほぼ $0.02 \mathrm{cal} /$ $\mathrm{cm}^{2} \cdot \mathrm{s} \cdot \mathrm{deg}$ である. また凝固鋳塊一鋳型内冷却水間の総 括伝熱係数はこれらより 1 桁小さい.

(3) スラグ殸の有効熱伝導率は， $\mathrm{CaO}-\mathrm{Al}_{2} \mathrm{O}_{3}$ スラ グでは $2.2 \times 10^{-3} \mathrm{cal} / \mathrm{cm} \cdot \mathrm{s} \cdot \mathrm{deg}$ であり， $\mathrm{CaF}_{2}$ 量とと もに著しく増大寸る.

（4） スラグ浴ースラグ殸-鋳型-冷却水間の温度勾配 は，酸化物系スラグでは大ラグ浴内で緩やかであり，ス ラグ殸内に拉いて急である.いつぽら，フッ化物系スラ グではスラグ浴の温度はスラグ款近傍までほぼ一様であ り，スラグ殼内の温度勾配も緩やかであるが, スラグ殸鋳型間にかなり大きい温度差を生ずる，したがつて，酸 化物系スラグではスラグ殼それ自体が，またフッ化物系 スラグではスラグ殼とともにスラグ殼-鋳型間の接触伝 熱抵抗も主要な伝熱抵抗となる.

（5）このよらな伝熱挙動の違いが電極の融解速度や メタル浴の形状におよぼす影響は非常に大きく，酸化物 系スラグを使用することにより，電力原単位の低減をは かることができるとともに，表層部の凝固組織の緻密な 鋳塊を得ることがでさる。

\section{交献}

1) A. Mitchell and $S$. Joshi : Met. Trans., 4 (1973), p. 631

2) 川上正博, 永田和宏, 山村 稔, 坂田直起, 宮下 芦雄，後藤和弘：鉄と鋼，63 (1977)，p. 2162

3 ) 小口征男, 旦部祐二郎, 深山三郎, 江島涁夫 : 鉄 と鋼， 63 (1977)，p. 2152

4) A. H. Dilawari and $J$. Szekely : Met. Trans., 9B (1978), p. 77

5 ) 井上道雄, 岩崎哲夫, 浅井滋夫 : エレクトロスラ グ再溶解法の物理化学と技術的諸問題，鉄鋼基礎 共同研究会特殊精錬部会編 - 日本鉄鋼協会 (1979), p. 55

6 ) $J$. Kreyenberg and $K$. Schwerdtfeger : Arch. Eisenhüttenw., 50 (1979), p. 1

7 ) B. E. Paton, B. I. Medovar, V. L. Shevtzov, G. S. MARinsky, and $V . I$. SAGAN : Proc. 5th Intern. Symp. on Electroslag and Other Special Melting Technology, Pittsburgh, (1974), p. 410

8 ) A. Mitchell and $S$. Joshi : Met. Trans., 2 (1971)， p. 449

9 ) 飯島史郎, 近藤保夫：エレクトロスラグ再溶解法 の物理化学々技術的諸問題，鉄鋼基礎共同研究会 特殊精錬部会編 (1979)， p. 89 日本鉄鋼協会

10)成田貴一, 尾上俊雄, 石井照朗, 草道龍彦: 鉄之 鋼, 64 (1978), p. 1568

11）鉿木 章，永田弘之，広瀬和夫：鉄と鋼. 65 (1979)，Ｓ124，エレクトロスラグ 再溶解法の物 理化学々技術的諸問題，鉄鋼基礎共同研究会 - 特 殊精錬部会編 (1979), p. 132 日本鉄鋼協会

12）荻野和己，西脇 醇：エレクトロスラグ再溶解の 物理化学と技術的諸問題, 鉄鋼基礎共同研究会 · 特殊精錬部会編（1979)，p. 89 日本鉄鋼協会

13) R. H. NAfZiger : High Temp. Sci., 5 (1973) p. 414

14) 石井邦宜, 山本澄夫，佐藤修治，近藤真一，吉井 周雄 : エレクトロスラグ再溶解法の物理化学と技 術的諸問題, 鉄鋼基礎共同研究会 - 特殊精鍊部会 編 (1979)，p. 18 日本鉄鋼協会

15）梅田高照：エレクトロスラグ再溶解法の物理化学 と技術的諸問題, 鉄鋼基礎共同研究会, 特殊精錬 部会編 (1979)，p. 173 日本鉄鋼協会

16）エレクトロスラグ再溶解スラグの性質，特殊精錬 部会・第 4 分科会編 $(1979)$ 日本鉄鋼協会

17) E. N. Sieder and G. E. TAte : Ind. Eng. Chem., 28 (1936), p. 1429

18) 成田貴一, 尾上俊雄, 石井照朗, 草道龍彦: 学振 第 140 委資料 76 (1978)

19）溶鉄 - 溶㵏の物性值便覧，日本鉄鋼協会溶鋼 - 溶 滓部会編 (1972)

20) $W$. Holzgruber and E. Plöckinger : Stahl u. Eisen, 88 (1968), p. 638

21）ESR 鋼塊，鋼材の欠陥事例集，特殊精錬部会 · 第 2 分科会編 (1977) 日本鉄鋼協会 